GRASAS Y ACEITES, 63 (2),

ABRIL-JUNIO, 175-183, 2012,

ISSN: 0017-3495

DOI: $10.3989 /$ gya.082811

\title{
Prospects of fatty acid profile and bioactive composition from lipid seeds for the discrimination of apple varieties with the application of chemometrics
}

\author{
By S. Arain ${ }^{1}$, S.T.H. Sherazi ${ }^{1, *}$, M.I. Bhanger ${ }^{1}$, N. Memon ${ }^{1}$, S.A. Mahesar ${ }^{1}$ and M.T. Rajput ${ }^{2}$ \\ ${ }^{1}$ National Centre of Excellence in Analytical Chemistry, University of Sindh, Jamshoro-76080, Pakistan. \\ ${ }^{2}$ Institute of Plant Sciences, University of Sindh, Jamshoro-76080, Pakistan \\ ${ }^{*}$ Corresponding author: tufail.sherazi@yahoo.com
}

\section{RESUMEN}

Perspectivas del perfil de ácidos grasos y la composición de lípidos bioactivos de semillas en la discriminación de variedades de manzana mediante quimiometría.

Se ha estudiado el perfil de ácidos grasos y lípidos biactivos mediante GC-MS del aceite extraído de semillas de cuatro variedades de manzanas de Pakistán (Royal Gala, Red Delicious, Pyrus Malus y Golden Delicious). El contenido de aceite en las semillas de las variedades de manzanas estudiadas oscilaron desde 26,8 hasta $28,7 \%$. Los resultados mostraron que el ácido linoleico (40.5-49.6\%) fue el principal ácido graso de las semillas de las variedades Royal Gala, Red Delicious y Pyrus Malus, y el ácido oleico (38,7-45,5\%) fue el principal ácido graso de Golden Delicious. Los ácidos palmítico (6.1-7.4\%) y esteárico $(2,0-3,1 \%)$ fueron los ácidos grasos saturados predominantes, las semillas contenían también pequeñas cantidades de palmitoleico, heptadecanoico, linolénico, araquídico, eicosanoico, y behénico. Esteroles, tocoferoles, hidrocarburos, y otros componentes menores también fueron identificados a partir de la fracción insaponificable. La variación de los resultados de ambos, ácidos grasos y lípidos bioactivos, de cuatro variedades diferentes se evaluó mediante análisis de componentes principales, análisis discriminante y análisis de cluster. Los resultados concluyen que las dos fracciones lipídicas de semillas de manzanas podrían aplicarse como una herramienta útil para distinguir variedades.

PALABRAS CLAVE: Composición de ácidos grasos Extracción de aceite - Lípidos bioactivos - Quimiometría Semillas de variedades de manzanas.

\section{SUMMARY}

Prospects of fatty acid profile and bioactive composition from lipid seeds for the discrimination of apple varieties with the application of chemometrics.

The extracted oils from four apple seed varieties (Royal Gala, Red Delicious, Pyrus Malus and Golden Delicious) from Pakistan were investigated for their fatty acid profiles and lipid biactives by GC-MS. The oil contents in the seeds of the apple varieties ranged from $26.8-28.7 \%$. The results revealed that linoleic acid (40.5-49.6\%) was the main fatty acid in the Royal Gala, Red Delicious and Pyrus Malus seeds, and oleic acid $(38.7-45.5 \%)$ was the main fatty acid in the Golden Delicious seeds. Palmitic acid (6.1-7.4\%) and stearic acid (2.0-3.1\%) were the dominant saturated fatty acids, besides the small amount of palmitoleic, heptadecanoic, linolenic, archidic, eicosanoic, and behenicacids. Sterols, tocopherols, hydrocarbons and some other minor components were also identified from the unsaponifiable lipid fraction. The variation among the results of both fatty acids and lipid bioactives for the four different varieties was assessed by principal component analysis, discriminant analysis and cluster analyses. The results conclude that both oil fractions could be applied as a useful tool to discriminate among the apple seed varieties.

KEY-WORDS: Apple seed varieties - Chemometrics - Crude oil extraction - Fatty acid composition - Lipid bioactives.

\section{INTRODUCTION}

The apple is commonly considered to be the health complimentary table fruit of the world. It is one of the most widely cultivated fruits. It belongs to the family Rosaceae and sub family Maloideae, including approximately 28 genera, and 1100 species worldwide. The apple is the most important commercial fruit crop of North America and Europe. Apple trees, are found throughout temperate zones of the northern hemisphere (Rohrer et al., 1994). Apples are grown in northwestern hilly tracts of the Indo Pak sub-continent. In Pakistan, Quetta, Pishin, Ziarat, Mustang, Kalat, Kashmir, Chitral, Swat, Hunza and other areas over $1000 \mathrm{~m}$ above the sea level are apple growing regions (Tareen et al., 2003). The total area under apple cultivation in Pakistan is 110.8 thousand hectares which include 0.4 Punjab, 0.1 Sindh, 8.8 NWFP and 101.5 thousand hectare Balochistan while the total production in Pakistan is 333.8 thousand tons which includes 3.6 Punjab 0.1 Sindh, 106.3 NWFP and 223.8 thousand tons Balochistan (Agricultural Statistics of Pakistan, 2004; Iftikhar et al., 2009). The apple is an extremely nutritive food containing sugar, protein, carbohydrates and vitamins in a balanced form. The apple fruit is used in the preparation of many products such as salads, jams, jellies, marmalades, snacks, and in many dishes such as puddings, sweet meats, pickles and other preserves include pie filling, slices and sauces. Sour varieties of the apple are used for the preparation of fermented apple juice such as cider (Hulme, 1970). The direct utilization of apples is associated with the prevention of various chronic diseases and apple juice inhibits human low density lipoprotein oxidation (Hamauzu et al., 2005; Boyer and Liu, 2004; Pearson et al., 1999) and apple 
peel phytochemicals have potent antioxidant activity and antiproliferative activity against human cancer cells (Oleszek et al., 1988; Wolfe et al., 2003; Liu et al., 2005; Xiangjiuand Rui, 2008). Only a few studies are available on the proximate composition of the apple seed and characterization of its oil, the constitution of some chemical components of apple seeds, the influence of cultivar and storage time on the contents of higher fatty acids in the apple cuticle and the fatty acid composition of apple and pear seed oils, (Yu et al., 2007; Luand Yeap Foo, 1998; Marjan et al., 2007; Yukui et al., 2009).

Two ancient, late-bearing apple varieties (cv. 'Diacciata' and 'Limoncella') were characterized using micromorphological, genetic and biochemical approaches, and by comparison with two commercial varieties, 'Gala' and 'Golden Delicious' (Chen et al., 2011). Discrimination among apple juices produced from different varieties (Spartan, Bramley, Russet) was evaluated by applying principal components analysis (PCA) and linear discriminant analysis to ${ }^{1} \mathrm{H}$-NMR spectra of the juices (Belton et al., 1998). The potential of visible/near-infrared (Vis/NIR) spectroscopy for its ability to nondestructively differentiate apple varieties was explored by Yong et al. (2007). The apple varieties used in their research included Fuji apples, Red Delicious apples, and Copefrut Royal Gala apples. The chemometric procedures applied to the Vis/NIR data were principal component analysis (PCA), wavelet transformation (WT), and artificial neural network (ANN) and two ancient, late-bearing apple varieties (cv. 'Diacciata' and 'Limoncella') were characterized using micromorphological, genetic and biochemical approaches, and by comparison with two commercial varieties, 'Gala' and 'Golden Delicious'. There were significant differences between the two varieties (Minnocci et al., 2010). In the present study, four apple seed varieties were evaluated for lipid bioactives such as fatty acids, sterols, tocopherols, hydrocarbons and other minor compounds by GCMS with the combination of principal component analysis (PCA), linear discriminant analysis (LDA) and Hierarchical clustering analysis (HCA).

\section{MATERIALS AND METHODS}

\subsection{Samples and chemicals}

Four different varieties of apples (Royal Gala, Red Delicious, Pyrus Malus and Golden Delicious) were selected for the study. Two samples of each variety were collected from 10 different locations of Pakistan; Quetta, Pishin, Ziarat, Mustang, Kalat, Kashmir, Chitral, Swat, Hunza and Gilgit. Apples of selected varieties were picked from the trees located in ten different locations from the beginning of August to the end of the December, 2009. All collected samples were analyzed in duplicate. Apples were crushed for the seed segregation and the seeds of each sample were stored in cellophane bags at $4{ }^{\circ} \mathrm{C}$ prior to analysis. For the extraction of oil approximately $5 \mathrm{~g}$ of seed from each variety were used. All reagents, chemicals and solvents used were of analytical grade purchased from E. Merck (Darmstadt, Germany). Fatty acid methyl esters (FAME) standards (GLC 481-B and 607) were purchased from Nu-Check-Prep, Inc. (Elysian, MN).

\subsection{Oil extraction}

Crude oil from the ground seeds $(\sim 5 \mathrm{~g})$ of each variety was extracted with $n$-hexane in a Soxhlet extractor for $6 \mathrm{~h}$. The solvent was then removed using a rotary evaporator under reduced pressure; the oil was flushed with a stream of nitrogen and stored at $-20^{\circ} \mathrm{C}$ in sealed tubes prior to analyses.

\subsubsection{Determination of fatty acid methyl esters}

The fatty acid profiles of the seed oils were obtained as fatty acid methyl esters. These were prepared by using $20 \mathrm{~mL}$ of methanol with 2-3 pellets of $\mathrm{KOH}$ and reflux for $30 \mathrm{~min}$. The esters were extracted into hexane washed with water and dried over anhydrous sodium sulphate, according to the standard method 2.301 (IUPAC, 1979). The GC-MS analysis for FAMEs was performed on an Agilent $6890 \mathrm{~N}$ gas chromatography instrument coupled with an Agilent MS-5975 inert XL mass selective detector and an Agilent autosampler 7683-B injector (Agilent Technologies, Little Fall, NY, USA). A capillary column HP5 MS (5\% phenyl methylsiloxane) of $30 \mathrm{~m} \times 0.25 \mathrm{~mm}$ i.d $\times 0.25 \mu \mathrm{m}$ film thickness (Agilent Technologies, Palo Alto, CA, USA) was used for the separation of fatty acid methyl esters. The initial temperature of $150^{\circ} \mathrm{C}$ was maintained for $2 \mathrm{~min}$ raised to $230^{\circ} \mathrm{C}$ at the rate of $4^{\circ} \mathrm{C} / \mathrm{min}$, and kept at $230^{\circ} \mathrm{C}$ for $5 \mathrm{~min}$. The split ratio was $1: 50$, and helium was used as a carrier gas with the flow rate of $0.8 \mathrm{~mL} / \mathrm{min}$. The injector and detector temperatures were 240 and $260^{\circ} \mathrm{C}$, respectively. The mass spectrometer was operated in the electron impact (EI) mode at $70 \mathrm{eV}$ in the scan range of $50-550 \mathrm{~m} / \mathrm{z}$. GC-MS chromatogram obtained were compared with two libraries (NIST \& Wily) which provide best information about the identification of fatty acid present in these oil samples.

\subsubsection{Determination of bioactive compounds}

The GC-MS analysis of the unsaponifiable fraction of apple seed oil for bioactive constituents such as sterols, tocopherols, hydrocarbons and other components present was also carried out. The separation of unsaponifiable was performed by the saponification of the oil samples but without any derivatization. Saponification oil was performed according to the reported method (Ramadan and Morsel, 2003), with minor changes. Apple seed oil $(250 \mathrm{mg}$ ) was refluxed with $5 \mathrm{~mL}$ of ethanolic potassium hydroxide solution $(6 \%, w / v)$ in the presence of a few anti-bumping granules for $60 \mathrm{~min}$. The unsaponifiables were first extracted 3-times with $10 \mathrm{~mL}$ of $\mathrm{n}$-hexane; the extracts were combined and washed 3-times with 
$10 \mathrm{~mL}$ of neutral ethanol/water $(1: 1, \mathrm{v} / \mathrm{v})$ and then dried overnight with anhydrous sodium sulphate. The extract was evaporated in a rotary evaporator at $25^{\circ} \mathrm{C}$ under reduced pressure, and then dissolved in $1 \mathrm{~mL}$ $\mathrm{n}$-hexane. The unsaponifiable profile was analyzed on the same equipment used for fatty acid analysis and a capillary column HP-5MS (5\% phenyl methylsiloxane) of $30 \mathrm{~m} \times 0.25 \mathrm{~mm}$ i.d $\times 0.25$ micronfilm thickness (Agilent Technologies, Palo Alto, CA, USA) was used for the separation of unsaponifiables (hydrocarbons, tocopherols, sterols, alcohols and other compounds). The initial temperature of $250^{\circ} \mathrm{C}$ was maintained for 2 min, raised to $310^{\circ} \mathrm{C}$ at the rate of $15^{\circ} \mathrm{C} / \mathrm{min}$, and held at $310^{\circ} \mathrm{C}$ for $10 \mathrm{~min}$. The split ratio was 1:50; helium was used as a carrier gas with a flow rate of $1.2 \mathrm{~mL} /$ $\min$. The injector and detector temperatures were 240 and $260^{\circ} \mathrm{C}$, respectively. The mass spectrometer was operated in the electron impact (EI) mode at $70 \mathrm{eV}$; ion source temperature $230^{\circ} \mathrm{C}$; quadrupole temperature $150^{\circ} \mathrm{C}$; translating line temperature $270^{\circ} \mathrm{C}$; the mass scan ranged from 50-550m/z; Em voltage $1035 \mathrm{~V}$. The identification of sterols, tocopherols, hydrocarbons, alcohols and other compounds was based on the comparison of their relative retention times with those of authentic standards. The sterols, tocopherol, hydrocarbons, alcohols and other compounds were also identified and authenticated by their MS spectra compared to those from the NIST \& Wily mass spectral library. The quantification was done by Chemstation data handling software Agilent-Technologies.

\subsection{Data analysis}

In the present work, simple chemometric criteria was used on the bases of fatty acid composition and lipid bioactives present in the apple seed oil to distinguish among the varieties of apple. An analytical study was carried out for each variable individually used to test the differences among varieties, with One Way ANOVA (Minitab Scan, Release 1, 1995). The multivariate test of significance was also applied for the determination of Wilk's lambda (measurement of group differences among twenty-nine variables). The principal components analysis (PCA) was performed to identify the design for the interaction among variables, categorization and division of each variety. Variables used in PCA were selected on the basis of ANOVA results. Eigen values were also examined for each analysis; three factors were enough to explain all the variability. Cluster analysis was also applied in order to explore the grouping of samples according to the similarities, which occur in discriminant parameters using the specific software (Statgraphics Plus software, 1998). Principal component analysis (PCA), hierarchical cluster analysis (HCA), and linear discriminant analysis were examined with using the Statgraphic Plus software (Manugistic Inc Rockville MD USA).

\section{RESULTS AND DISCUSSION}

The data produced from the two classes of the compounds were interpreted by using summarized descriptive statistics with $F$ and $p$ values for four apple seed varieties of oils and are presented in Tables 1 and 2 . In the examination of the data in Tables 1 and 2, the large differences and clear similarities among the four varieties of oils and the levels of the variation were observed depending on the class of compounds considered.

\subsection{Fatty acid composition}

The oil content in the seeds of four varieties of apples ranged from $26.8-28.9 \%$ (Table 1 ). From the data presented it could be seen that highest oil content

Table 1

Fatty acid compositional data (\%) of apple seed oils with statistical analysis

\begin{tabular}{|c|c|c|c|c|c|c|c|c|c|}
\hline \multirow{2}{*}{$\begin{array}{l}\text { Classes of } \\
\text { Compounds } \\
\text { (Variables) }\end{array}$} & \multicolumn{2}{|c|}{ Royal Gala } & \multicolumn{2}{|c|}{ Red Delecious } & \multicolumn{2}{|c|}{ Pyrus Malus } & \multicolumn{2}{|c|}{$\begin{array}{l}\text { Golden } \\
\text { Delicious }\end{array}$} & \multirow{2}{*}{$\begin{array}{c}\text { ANOVAc }^{c} \\
\text { F-observed }\end{array}$} \\
\hline & $\begin{array}{c}\text { Mean } \\
(\%)\end{array}$ & $\begin{array}{l}S D^{b} \\
( \pm)\end{array}$ & $\begin{array}{c}\text { Mean } \\
(\%)\end{array}$ & $\begin{array}{l}\text { SD } \\
( \pm)\end{array}$ & $\begin{array}{c}\text { Mean } \\
(\%)\end{array}$ & $\begin{array}{l}\text { SD } \\
( \pm)\end{array}$ & $\begin{array}{c}\text { Mean }^{a} \\
(\%)\end{array}$ & $\begin{array}{l}\text { SD } \\
( \pm)\end{array}$ & \\
\hline Oil content & 27.2 & 1.1 & 27.6 & 0.8 & 28.9 & 0.9 & 26.8 & 1.7 & 3.4 \\
\hline Palmitic ( C16:0) & 7.4 & 0.5 & 6.7 & 0.3 & 6.1 & 0.4 & 7.1 & 0.4 & 15.6 \\
\hline Palmitoleic (C16:1) & 0.1 & 0.0 & 0.1 & 0.0 & 0.2 & 0.0 & 0.1 & 0.0 & 18.7 \\
\hline Heptadecanoic (C17:0) & 0.1 & 0.0 & 0.1 & 0.0 & 0.0 & 0.0 & 0.1 & 0.0 & 64.4 \\
\hline Stearic (C18:0) & 2.5 & 0.6 & 2.3 & 0.3 & 2.0 & 0.4 & 3.1 & 0.3 & 14.7 \\
\hline Oleic (C18:1) & 41.7 & 1.1 & 39.3 & 2.7 & 38.7 & 1.7 & 45.5 & 2.1 & 36.9 \\
\hline Linoleic (C18:2) & 45.1 & 3.6 & 47.8 & 3.5 & 49.6 & 2.2 & 40.5 & 1.6 & 25.4 \\
\hline Linolenic (C18:3) & 0.3 & 0.1 & 0.3 & 0.1 & 0.4 & 0.0 & 0.3 & 0.0 & 8.8 \\
\hline Ecosanoic (C20:0) & 1.7 & 0.2 & 2.0 & 0.2 & 0.9 & 0.1 & 2.0 & 0.2 & 51.2 \\
\hline 11-Ecosenoic ( C20:1) & 0.7 & 0.2 & 1.0 & 0.1 & 0.6 & 0.0 & 0.7 & 0.0 & 14.6 \\
\hline Docosanoic (C22:0) & 0.4 & 0.1 & 0.5 & 0.0 & 0.7 & 0.0 & 0.6 & 0.1 & 12.3 \\
\hline
\end{tabular}

\footnotetext{
${ }^{a}$ mean values in percentage within each class of fatty acids; ${ }^{b}$ standard deviation; ${ }^{c}$ analysis of variance, probability $<0.001$.
} 
Table 2

Unsaponifiable compositional data (\%) of apple seed oils with statistical analysis

\begin{tabular}{|c|c|c|c|c|c|c|c|c|c|}
\hline \multirow{2}{*}{$\begin{array}{l}\text { Classes of } \\
\text { compounds } \\
\text { (Variables) }\end{array}$} & \multicolumn{2}{|c|}{ Royal Gala } & \multicolumn{2}{|c|}{ Red Delicious } & \multicolumn{2}{|c|}{ Pyrus Malus } & \multicolumn{2}{|c|}{$\begin{array}{c}\text { Golden } \\
\text { Delicious }\end{array}$} & \multirow{2}{*}{$\begin{array}{c}\text { ANOVA }^{\mathrm{C}} \\
\text { F- observed }\end{array}$} \\
\hline & Mean $^{a}$ & $\begin{array}{l}\text { SD } \\
( \pm)\end{array}$ & Mean $^{a}$ & $\begin{array}{l}\text { SD } \\
( \pm)\end{array}$ & Mean $^{a}$ & $\begin{array}{l}\text { SD } \\
( \pm)\end{array}$ & Mean $^{a}$ & $\begin{array}{l}\text { SD } \\
( \pm)\end{array}$ & \\
\hline $\begin{array}{l}\text { Hexadecanoic acid, } \\
\text { ethyl ester }\end{array}$ & 7.2 & 0.5 & 7.4 & 0.4 & 6.6 & 0.3 & 5.7 & 0.2 & 23.2 \\
\hline Phytol & 3.5 & 0.7 & 1.6 & 0.2 & 0.6 & 1.1 & 1.1 & 0.5 & 28.6 \\
\hline Ethyl Oleate & 39.2 & 1.6 & 38.6 & 2.1 & 34.6 & 3.1 & 35.5 & 1.9 & 15.6 \\
\hline 9-hexadecenal & 3.2 & 0.7 & 1.5 & 0.2 & 0.7 & 0.4 & 0.8 & 0.2 & 32.8 \\
\hline 3-Eicosene & 0.9 & 0.1 & 0.8 & 0.1 & 0.8 & 0.2 & 0.7 & 0.3 & 8.5 \\
\hline $\begin{array}{l}\text { Octadecanoic acid, } \\
\text { ethyl ester }\end{array}$ & 1.3 & 0.1 & 0.9 & 0.1 & 2.9 & 1.1 & 1.8 & 0.9 & 34.8 \\
\hline 1-Docasene & 2.7 & 0.2 & 2.8 & 0.2 & 2.4 & 0.3 & 2.6 & 0.1 & 10.3 \\
\hline Docosane & 0.9 & 0.1 & 0.8 & 0.1 & 0.9 & 0.5 & 0.9 & 0.4 & 8.6 \\
\hline 1-Hexacosene & 1.1 & 0.1 & 1.0 & 0.1 & 1.2 & 1.2 & 0.8 & 0.6 & 37.2 \\
\hline Octacosane & 0.8 & 0.1 & 0.9 & 0.2 & 0.8 & 0.4 & 0.9 & 0.3 & 8.7 \\
\hline Squalene & 6.7 & 1.2 & 5.7 & 0.5 & 5.8 & 0.8 & 6.4 & 1.2 & 9.4 \\
\hline Nonacosane & 1.4 & 0.2 & 1.2 & 0.2 & 0.9 & 0.3 & 1.5 & 0.5 & 8.5 \\
\hline$\beta$-Tocopherol & 1.4 & 0.2 & 1.7 & 0.4 & 1.7 & 0.5 & 1.8 & 0.7 & 17.2 \\
\hline$\alpha$-Tocopherol & 6.4 & 1.1 & 5.4 & 0.8 & 6.1 & 0.6 & 5.6 & 0.6 & 8.6 \\
\hline Campesterol & 0.8 & 0.1 & 0.5 & 0.0 & 0.7 & 0.2 & 0.9 & 0.3 & 9.6 \\
\hline Avenasterol & 0.6 & 0.0 & 0.6 & 0.0 & 0.6 & 0.1 & 0.8 & 0.2 & 13.4 \\
\hline$\beta$-sitosterol & 16.2 & 1.1 & 14.8 & 1.1 & 13.6 & 1.4 & 15.9 & 1.2 & 69.3 \\
\hline $\begin{array}{l}\text { 9,19-Cyclolanost-24- } \\
\text { en-3-ol }\end{array}$ & 3.2 & 0.3 & 3.7 & 0.5 & 3.6 & 1.1 & 4.6 & 0.6 & 26.5 \\
\hline Stigmast-4-en-3-one & 2.8 & 0.4 & 1.9 & 0.6 & 3.8 & 0.5 & 3.2 & 0.9 & 31.9 \\
\hline
\end{tabular}

${ }^{a}$ mean values in percentage within each class of fatty acids; ${ }^{b}$ standard deviation; ${ }^{c}$ analysis of variance, probability $<0.001$.

$28.9 \pm 0.9 \%$ was found in the seeds of the apple variety Pyrus Malus, while the lowest $26.8 \pm 0.7 \%$ was found in the seeds of Golden Delicious. The oil content of apple seed varieties obtained in this work agreed with that reported by $\mathrm{Yu}$ et al. (2007), Marjan et al. (2007) and Yukui et al. (2009). The principal fatty acid components in the apple seed oils were linoleic and oleic acids (Table 1). The linoleic acid was found to be the dominant fatty acid in Royal Gala $45.1 \pm 3.6 \%$, Red Delicious $47.8 \pm 3.5 \%$, and Pyrus Malus $49.6 \pm 3.3 \%$ respectively, while the Golden Delicious contained linoleic acid $40.5 \pm 2.1 \%$ in comparatively lower concentrations. It is notable that Golden Delicious oil could be easily distinguished from other varieties by the high level of oleic acid $45.5 \pm 1.4 \%$. Relatively lower percentages of oleic acid $39.3 \pm 2.7 \%$ was found in Red Delicious with respect to other varieties. The principal fatty acids i.e. linoleic and oleic acid in the present study were found to be quite comparable with the results of previously reported studies (Yu et al., 2007, Marjan et al., 2007; Yukui et al., 2009). The palmitic $6.1 \pm 0.4 \%$, stearic $3.1 \pm 0.3 \%$ and ecosenoic acid $1.0 \pm 0.1$ were found in Pyrus Malus with lower concentrations. Linolenic, palmitoleic, heptadecanoic, 11-ecosenoic and docosanoic acids were also identified in trace amounts $(<1 \%)$. The results revealed that the oils obtained through apple seeds are the richest source of linoleic and oleic acids. Dietary lipids, rich in linoleic and oleic acids, are beneficial for human health (Finley and Shahidi. 2001). Due to the appreciable content of oil and favorable fatty acid composition, the apple seeds oils have potential use as an edible oil (Yukui et al., 2009). The variation among the fatty acid compositions of their oils might be due to genetic features (Minnocci et al., 2010).

\subsection{Lipid bioactive composition}

Figure 1 represents the GC-MS chromatogram of the unsaponifiable lipid fraction of apple seeds. The composition of the unsaponifiable lipid fraction of the four apple seed varieties is shown in Table 2. The sterols are important constituents that improve the stability of the oil at high temperatures and act as inhibitors in polymerization reactions (Velasco and Dobarganes, 2002). $\beta$-sitosterol is responsible for the 


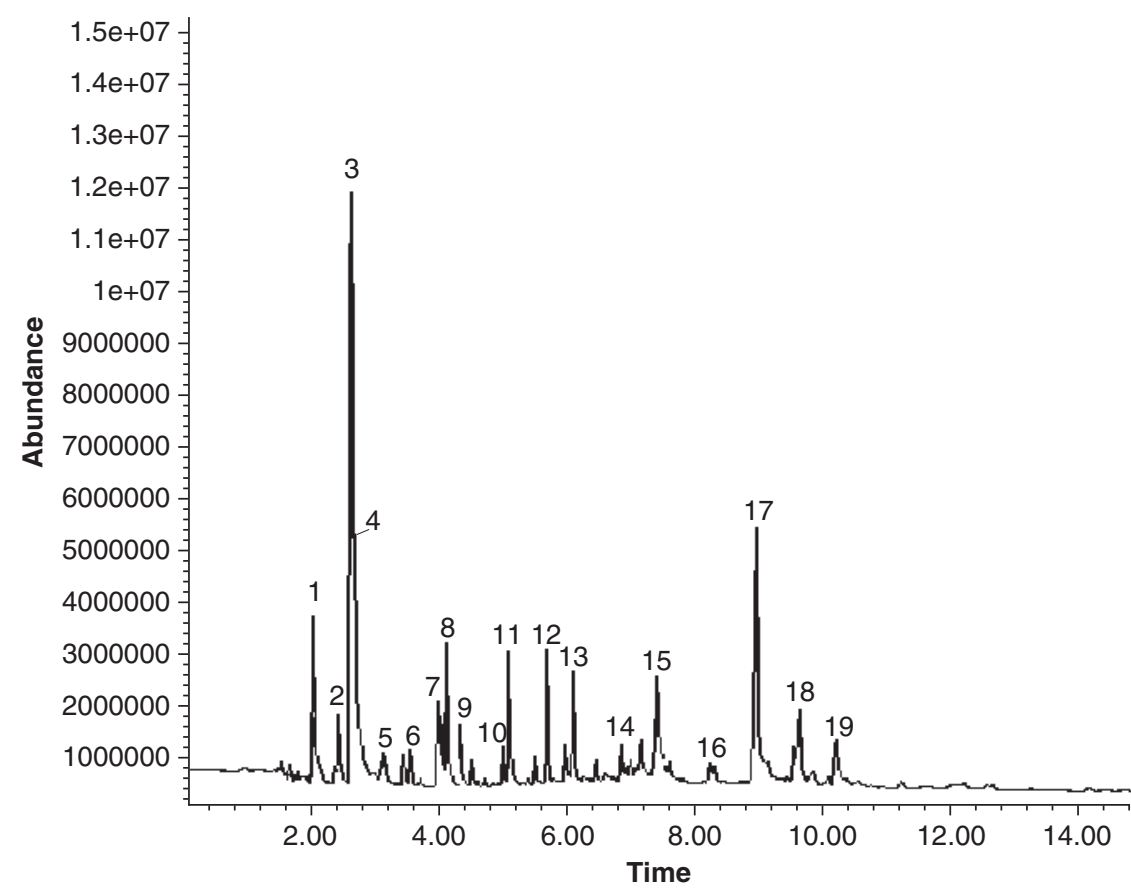

Figure 1

Representative GC-MS chromatogram of the unsaponifiable lipid fraction of apple seed.

(1) Hexadecanoic acid, ethyl ester, (2) phytol, (3) ethyloleate, (4) hexadecenal,

(5) 3-ecosene, (6) octadecanoic acid, ethyl ester, (7) 1-docasene, (8) docasene,

(9) 1-hexacosane, (10) octacosane, (11) squalene, (12) nonacosene, (13) $\beta$-tocpherol, (14) $\alpha$-tocopherol, (15) compesterol, (16) avenasterol, (17) $\beta$-sitosterol,

(18) 9,19-Cyclolanost-24-en-3-ol, (19) Stigmast-4-en-3-one.

preventive effects of diseases due to reactive oxygen species (Vivacons and Moreno, 2005). In all varieties, $\beta$-sitosterol was found to be predominant as compared to other detected sterols. In Royal Gala, the highest level of $\beta$-sitosterol, $16.17 \pm 0.7 \%$ was evaluated and followed by Red Delicious, $14.77 \pm 1.1 \%$, Pyrus Malus, $13.6 \pm 1.1 \%$ and Golden Delicious, $15.9 \pm 1.2 \%$ respectively. Cycloartenol $(9,19$-Cyclolanost-24-en-3-ol) is a well-known intermediate in the biosynthetic pathways of plant sterols (Wasuke et al., 1987). The highest percentage of 9, 19-cyclolanost-24-en-3-ol was observed in Golden Delicious, $4.8 \pm 0.6 \%$ as compared to other varieties. The hypoglycaemic effects of stigmast-4en-3-one have been reported (Alexander-Lindo et al., 2004). The highest level of stigmast-4-en-3-one was observed in Pyrus Malus, $4.6 \pm 0.6 \%$ as compared to the other varieties, which showed relatively lower amounts of Stigmast-4-en-3-one $(<4.00 \%)$. Avenasterol and campesterol were found in minor quantities $(<1 \%)$ in the apple seed varieties.

Tocopherols are the most important nutritional components, which are responsible for enhancing the stability of the oil in addition to other health benefits due to their antioxidant activity (Herrera and Barbas, 2001; Traber and Atkinson, 2007). In all samples (Table 2), the highest level of $\alpha$-tocopherol was observed in Royal Gala, $6.4 \pm 1.1 \%$ and $\beta$-tocopherol was found in the highest level in Golden Delicious, $1.8 \pm 0.7 \%$. Ethyl oleate was found to be a major constituent of the unsaponifiable lipid fraction of the apple seed varieties. Ethyl oleate is rapidly hydrolyzed to oleic acid, then absorbed and distributed within the body in a similar manner to oleic acid (Robert et al., 2003). As shown in Table 2, ethyl oleate was found in Royal Gala, $39.2 \pm 1.6 \%$, in a higher concentration. Hexadecanoic acid and octadecanoic acid and 9-hexadecenal were also identified. Squalene is the major hydrocarbon and represents more than $90 \%$ of the total hydrocarbons in the unsaponifiable lipid fraction of vegetable oils (Lanzón et al., 1994). Squalene protects the human skin from lipid peroxidation, and reduces low-density lipoprotein (LDL) as well as triglyceride levels in hypercholesterolemia (Kohno et al., 1995; Kelly et al., 1999). Table 2 clearly shows that Royal Gala contained $6.7 \pm 1.2 \%$ higher concentration of squalene and hydrocarbons such as 3-eicosene, octacosane, 1-docasene, docosane, 1-hexacosene, which were also detected in the oil. Phytol is commonly found in all plants and is the minor constituent of the human diet, as precursor for vitamins $E$ and $K_{1}$. $A$ number of studies have explored the various cellular and biological effects of phytols (Christiane et al., 1986; Hibasami et al., 2002). The lowest concentration of phytol was observed in Pyrus Malus $0.6 \pm 1.1 \%$ as compared to other varieties. The results indicated that variations in minor components were found among the different apple varieties.

\subsection{Chemometrics}

\subsubsection{Principal component analysis}

In this study, principal component analysis (PCA) was used on the fatty acid data matrix in order to 
identify a small number of factors that explain most of the variance observed in the variables and that could differentiate the apple seed varieties. According to the eigen values $(>1)$, the first three principal components were selected which correspond to $46.51,20.93$ and $18.80 \%$ variance of the original data, to collectively add up to $86.24 \%$ of the variance in the original data. Four groups of selected apple seed varieties were clearly discriminated in the scatter plot (Fig. 2a and b) by principal components (PC) 1 and 2. The majority of samples from the Royal Gala, Red Delicious and Golden Delicious varieties were clustered together quite closely. Only one cluster of Pyrus Malus was located away from these three groups. From the loading and biplot (Fig. 2a and b), Golden Delicious apples confirmed the correlation of C18:0, C18:1 and C16:0, whilse Royal Gala and Red Delicious were correlated with C17:0, C20:0 and C20:, while Pyrus Malus samples correlated with the C22:0, C16:1 and C18:2 which were supported by the previous study (Bianchi et al., 2001). The results of the PC1 and PC2 (Fig. 2a) as well as PC1 and PC3 (Fig. 2b) plots were proved excellent differentiations among the four groups of oils. Samples of Pyrus Malus varieties were differentiated from the others, but there is partial overlapping between Royal Gala, Red Delecious and Golden Delicious apple seed varieties. Royal Gala, Red Delicious and Golden Delicious apple seed oil samples were characterized by positive scores on PC1, whereas Pyrus Malus samples were prominently differentiated from the others groups due to their negative loading on PC2. The results revealed that all the variables at the same time allow for more satisfactory results in the differentiation of the four varieties. Different researchers applied PCA by selecting different approaches and chemical variables. For example, acidity (PC1) and phenolic compounds (PC2) were found to be the most relevant parameters for the discrimination of apple varieties (Del Campo et al., 2006). In another reported study, examination of the principal component loadings showed that the levels of malic acid and sucrose were two important variables, but variations in the composition of the minor constituents were also found to make a significant contribution to discrimination (Belton et al., 1998). In the present study, PCA was used to summarize the information of the data matrix in a more reduced way. Oleic acid (PC1) and linolenic acid (PC2) were the key contributors to the discrimination of apple varieties.

PCA was also applied to the unsaponifiable data matrix of the all samples. In first three PCs correspond to $46.31,16.75$ and $13.18 \%$ variance with eigenvalues $(>1)$, together they account for $76.24 \%$ of the variance in the original data. PCs plots for unsaponifiable data matrix revealed excellent differentiations of the four groups of oils. In PC 1, 2 and 3, Red Delicious apple samples, correlated with ethyl oleate and hexadecenal, Royal Gala correlated with squalene, phytol and $\beta$-sitosterol, and Golden Delicious correlated with avenasterol, campesterol and $\beta$-tocopherol whereas Pyrus Malus was correlated with stigmasterol and $\alpha$-tocopherol. Using PCA, Golden Delicious and Pyrus Malus apple seed

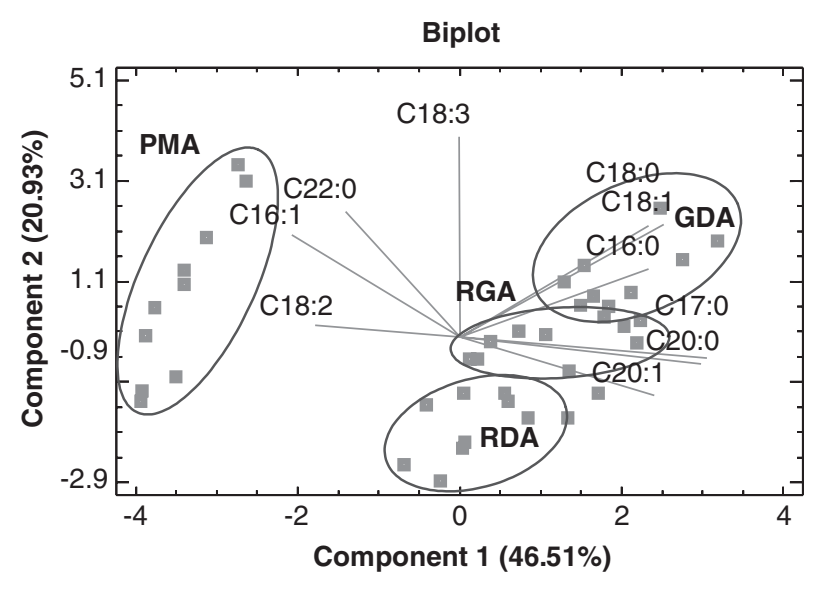

Figure 2a

PC1 verses PC2 of four varieties of apples based on fatty acid composition of RDA (Royal Gala apple), RDA (Red Delicious apple), PMA (Pyrus Malus apple), GDA (Golden Delicious apple).

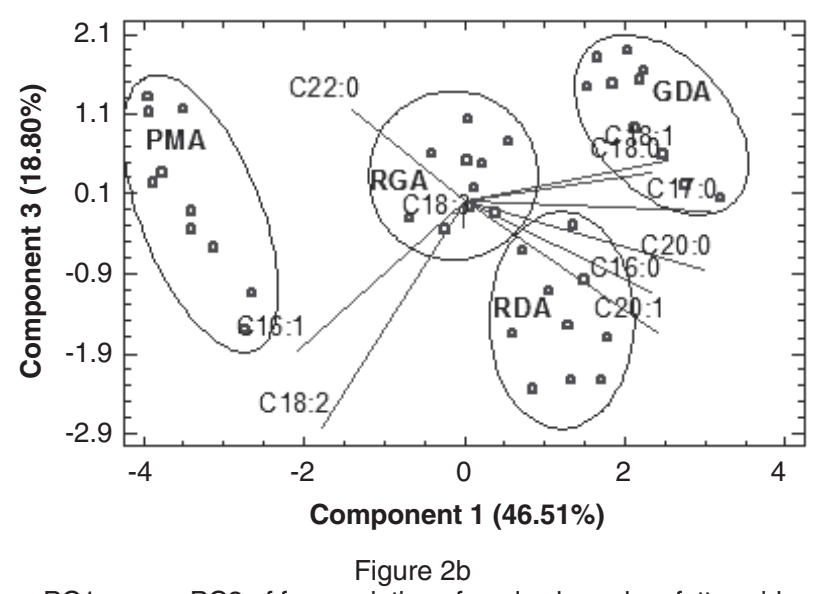

PC1 verses PC3 of four varieties of apples based on fatty acid composition of RGA (Royal Gala apple), RDA (Red Delicious apple), PMA (Pyrus Malus apple), GDA (Golden Delecious apple).

varieties were well differentiated from the others by all the variables while there was a partial overlapping between samples of Royal Gala and Red Delicious apple seed varieties as shown in a score plot (Fig. 3a and b). PCA was applied by some other authors on the composition of the minor constituents to discriminate the apple varieties (Chen et al., 2011; Belton et al., 1998). Their results also indicated that minor components could play considerable role to differentiate the apples varieties.

\subsubsection{Linear discriminant analysis}

Linear discriminant analysis was applied to the fatty acid composition data of the apple seed varieties, grouping them on the basis of the four linear associations (Fig. 4a). The eigenvalues, cumulative and the canonical correlation values were presented in Table 3. The first two discriminant functions explained $95.25 \%$ of the total variance. Four linear combinations were examined, because LDA selects directions which give maximum separation among the studied groups. The LDA plot (Fig. 4a) for the first two functions discriminated the Golden Delicious and Red 


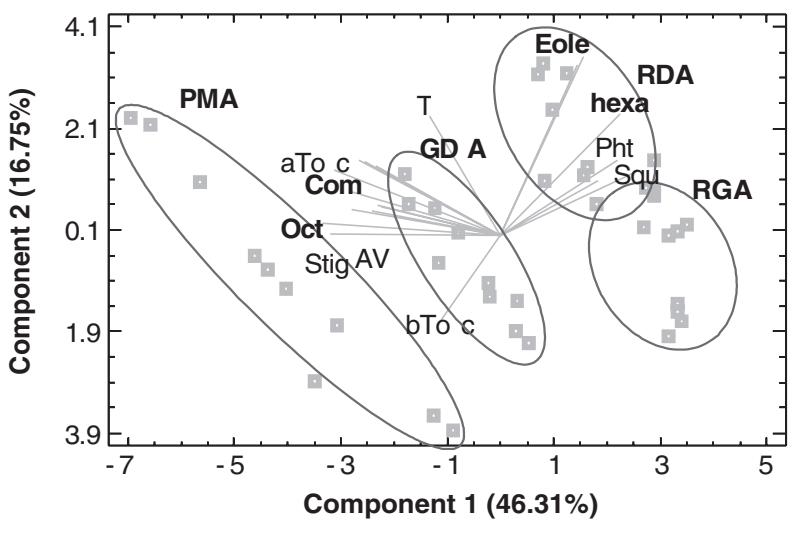

Figure $3 a$

PC1 verses PC2 of four varieties of apples based on unsaponifiable composition of RDA (Royal Gala apple), RDA (Red Delicious apple), PMA (Pyrus Malus apple), GDA (Golden Delicious apple) and Eole (Ethyl oleate), hexa (hexadecenal), Pht (Phytol), Squ (Squaline), sit ( $\beta$-Sitosterol),

aToc ( $\alpha$-Tocopherol), bToc ( $\beta$-Tocopherol), AV (Avenasterol), Stig (Stigmast-4-en-3-one), Cy (9,19-Cyclolanost-24-en-3-ol).

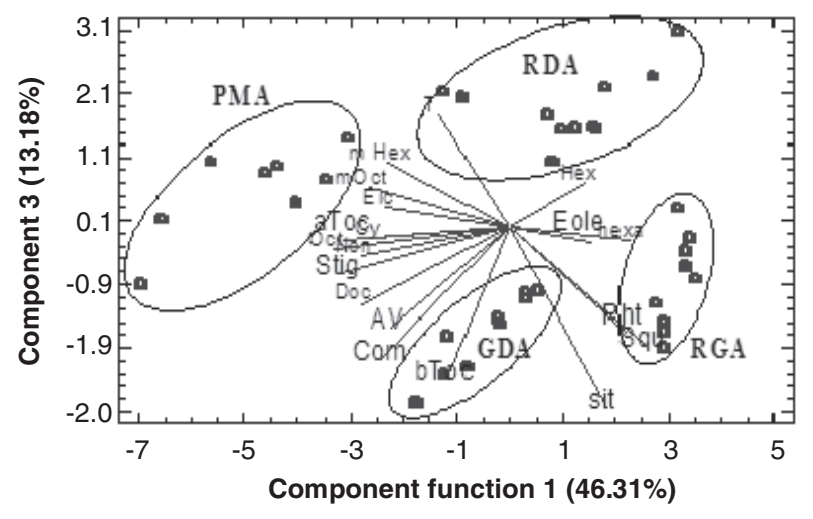

Figure $3 b$

PC1 verses PC3 of four varieties of apples based on unsaponifiable composition of RGA (Royal Gala apple), RDA (Red Delicious apple), PMA (Pyrus Malus apple), GDA (Golden Delicious apple) and Eole (Ethyl oleate), Pht (Phytol), Squ (Squaline), sit ( $\beta$-Sitosterol), aToc ( $\alpha$-Tocopherol), bToc

( $\beta$-Tocopherol), AV (Avenasterol), Stig (Stigmast-4-en-3-one), Cy (9,19-Cyclolanost-24-en-3-ol).

Delicious apple samples on negative half with partial overlapping, and Pyrus Malus apple samples were located on the positive half. The Red Delicious apple variety was discriminated along the linear functions
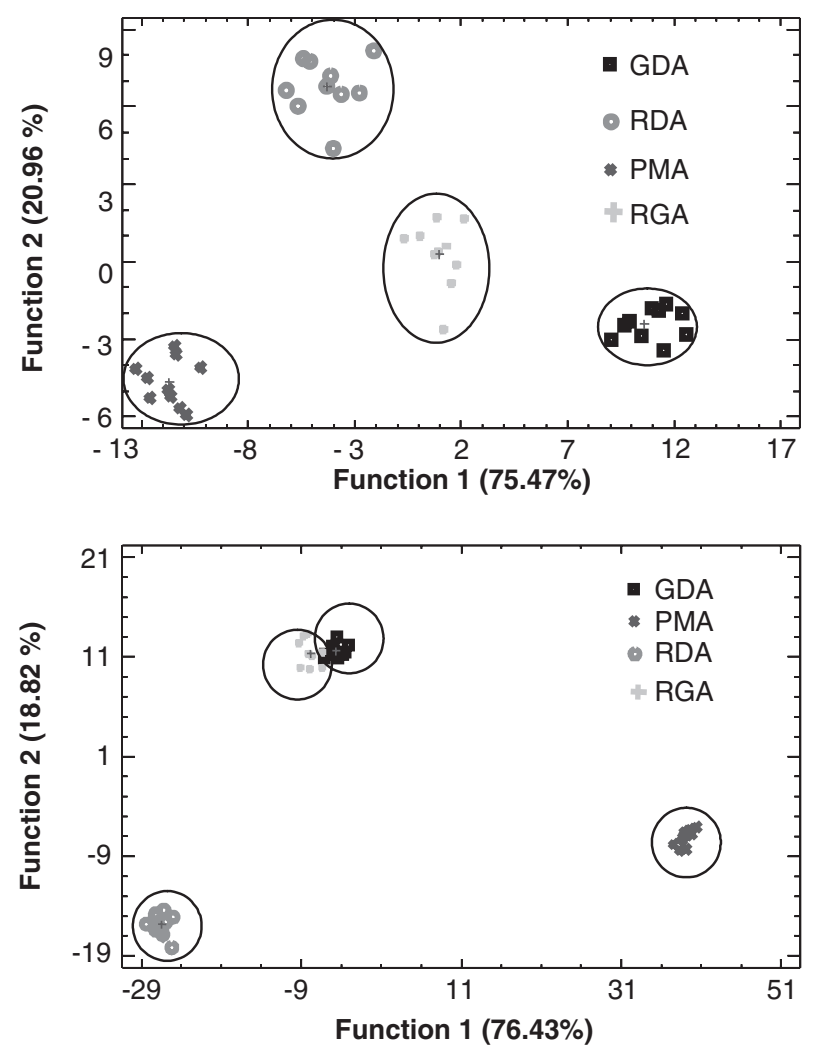

Figure 4

Discriminant function plots for four varieties of apples;

(a) based on fatty acid composition, (b) based on unsaponifiable composition of GDA (Golden Delicious apple), RDA (Red Delicious apple), PMA (Pyrus Malus apple), RGA (Royal Gala apple).

one and two (Fig. 4b). Eigenvalues, percent of variance, cumulative percentage and canonical correlation for discriminant functions revealed that all the groups were classified correctly by the model summarized in Table 3 . The first two discriminant functions explained $96.43 \%$ of the total variance. LDA plot (Fig. 4b) for the first two functions were discriminated the Red Delicious apple seed variety on the negative half, the Golden Delicious apple on the positive half, the Royal Gala apple sample lies in between the positive and the negative half (Ranalli et al., 2002), whereas Pyrus Malus samples were

Table 3

Linear discriminant analysis of fatty acids and unsaponifiables: statistics and classification of results

\begin{tabular}{|c|c|c|c|c|}
\hline $\begin{array}{l}\text { Discriminant } \\
\text { function }\end{array}$ & Eigenvalues & $\begin{array}{c}\text { Percent } \\
\text { of variance }\end{array}$ & $\begin{array}{l}\text { Cumulative } \\
\text { percentage }\end{array}$ & $\begin{array}{l}\text { Canonical } \\
\text { correlation }\end{array}$ \\
\hline \multicolumn{5}{|c|}{ Fatty acid composition } \\
\hline $\begin{array}{l}1 \\
2 \\
3\end{array}$ & $\begin{array}{r}74.03 \\
18.76 \\
1.48\end{array}$ & $\begin{array}{r}76.43 \\
18.82 \\
4.75\end{array}$ & $\begin{array}{r}76.43 \\
95.25 \\
100.00\end{array}$ & $\begin{array}{l}0.99 \\
0.97 \\
0.77\end{array}$ \\
\hline \multicolumn{5}{|l|}{ Unsaponifiables } \\
\hline $\begin{array}{l}1 \\
2 \\
3\end{array}$ & $\begin{array}{r}640.44 \\
157.74 \\
39.78\end{array}$ & $\begin{array}{r}75.47 \\
20.96 \\
3.57\end{array}$ & $\begin{array}{r}75.47 \\
96.43 \\
100.00\end{array}$ & $\begin{array}{l}0.99 \\
0.99 \\
0.98\end{array}$ \\
\hline
\end{tabular}




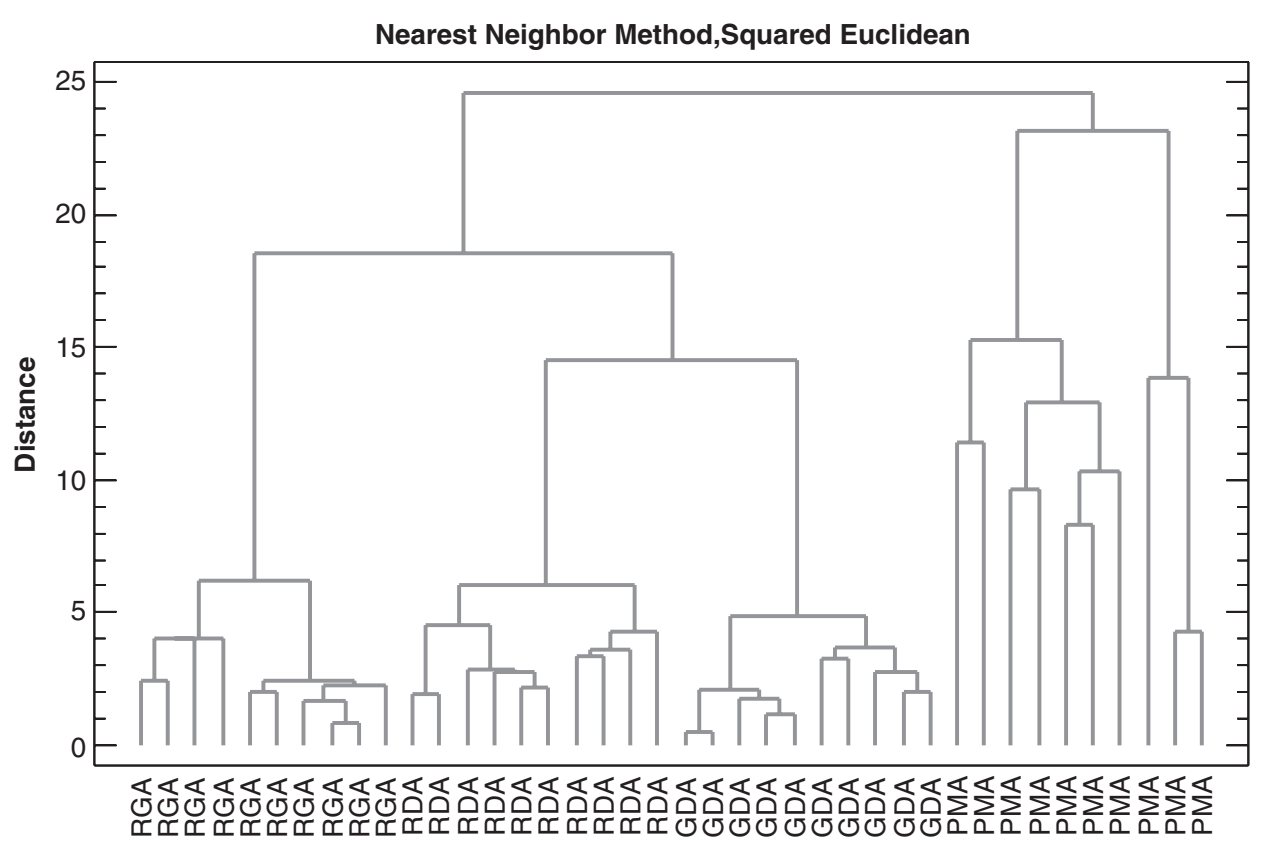

Figure 5.

Dedrogram for four apple varieties using unsaponifiable and fatty acid composition of RGA (Royal Gala apple), RDA (Red Delicious apple), GDA (Golden Delecious apple), PMA (Pyrus Malus apple).

differentiated along linear functions one and two as shown in Fig. 4b. The model for the classification (fatty acid and unsaponifiables) shows (Table 3) that all the cases were $100 \%$ correctly classified. The same apple varieties grown in different locations exhibited almost similar fatty acids and unsaponifiable contents indicating that genotypical changes may cause discrimination among apple varieties.

\subsubsection{Cluster analysis}

In hierarchical cluster analysis (HCA), distances between pairs of samples were calculated and compared. Relatively short distances between samples indicated similarity; dissimilar samples are separated by the large distances. The apple samples were classified into four groups. Cluster analysis was used to determine the pattern of clustering between the apple varieties (Del Campo et al., 2006). The results of the present study indicated that differentiation and combination of the groups were totally based on the similarities among the samples (Fig. 5). The major group contained the Royal Gala, Red Delicious, and Golden Delicious apple samples (Mildner-Szkudlarz et al., 2003), while the Pyrus Malus apple was separated by the large distances as an individual group which is clearly illustrated in Figure 5.

\section{CONCLUSIONS}

The results of the present study confirmed that fatty acids and unsaponifiable components are genuine parameters and indicators of the quality of oil and also suitable in chemometric techniques for the classification of apple seed varieties.
In this investigation, the performed chromatographic technique (GS-MS) gave valuable information about the composition of the apple seed oil. Fatty acid composition analysis of the apple seed oil revealed that a considerable amount of essential fatty acids and lipid bioactives are present in the apple varieties. The high level of linoleic acid content makes the oil nutritionally and industrially viable. Due to the significant level of unsaponifiable components such as tocopherols and sterols, the apple seed oil could be used in functional foods. Furthermore, the apple seed oil has great potential to be considered as a good source of oil for cosmetics, pharmaceutical, and edible purposes (Letawe et al. 1998; Darmstadt et al., 2002; Yukui et al., 2009).

\section{ACKNOWLEDGEMENT}

The authors would like to acknowledge the National Centre of Excellence in Analytical Chemistry, University of Sindh, Jamshoro, for the financial assistance to carry out the present work.

\section{REFERENCES}

Agricultural Statistics of Pakistan. 2004. Govt. of Pakistan Ministry of Food, Agriculture and Livestock, Economic Wing, Islamabad.

Alexander-Lindo RL, Morrison EY, Nair MG. 2004. Hypoglycaemic effect of stigmast-4-en-and its corresponding alcohol from the of Anacardium occidentale (cashew). Phytother. Res. 18, 403-407.

Belton PS, Colquhoun IJ, Kemsley EK, Delgadillo I, Roma P, Dennis, MJ, Sharman M, Holmes E, Nicholson JK, Spraul M. 1998. Application of chemometrics to the $1 \mathrm{H}$ NMR spectra of apple juices: Discrimination between apple varieties. Food Chem. 61, 207-213. 
Bianchi G, Giansante L, Shaw A, Kell DB. 2001. Chemometric criteria for the characterisation of Italian Protected Denomination of Origin (DOP) olive oils from their metabolic profiles. Eur. J. Lipid Sci. Technol. 103, 141-150.

Boyer J, Liu RH. 2004. Apple phytochemicals and their health benefits. Nutr. J. 3:5, Pub Med Central Full Text available.

Chen NN, Zhao SC, Deng LG, Guo CY, Mao JS, Zheng H, Yang GS, Lu X, Aboul-Enein HY. 2011. Determination of five polyphenols by HPLC/DAD and discrimination of apple varieties. Chromatographia 73, 595-598.

Christiane VB, Joseph V, Ingrid W, Frank R. 1986. Phytol and peroxisome proliferation. Pediatr. Res. 20, 411-415.

Darmstadt GL, Darmstadt GL, Mao-Qiang M, Chi E, Saha SK, Ziboh VA, Black RE, Santosham M, Elias PM, 2002. Impact of topical oils on the skin barrier possible implications for neonatal health in developing countries. Acta Paediatr. 5, 546-554.

Del Campo G, Berregi I, Iturriza N, Santos JI. 2006. Ripening and changes in chemical composition of seven cider apple varieties. Food Sci. Technol. Int. 12, 477-487.

Finley JW, Shahidi F. 2001. The chemistry, processing and health benefits of highly unsaturated fatty acids: an overview. In W. J. John \& F. Shahidi (Eds.), Omega-3 fatty acids, chemistry, nutrition and health effects (pp. 1-13). Washington, DC: American Chemical Society.

Hamauzu Y, Yasui H, Inno T, Kume Ch, Omanyuda M. 2005. Phenolic profile, antioxidant property, and antiinfluenza viral activity of Chinese quince (Pseudocydonia sinensis Schneid.), quince (Cydonia oblonga Mill.), and apple (Malus domestica Mill.) fruits. J. Agric. Food Chem. 53, 928-934.

Herrera E, Barbas C. 2001. Vitamin E: action, metabolism and perspectives. J. Physiol. Biochem. 57, 43-56.

Hibasami H, Kyohkon M, Ohwaki S, Katsuzaki H, Imai K, Ohnishi K, Ina K, Komiya T. 2002. Diol- and triol-types of phytol induce apoptosis in lymphoid leukemia Molt 4B cells. Int. J. Mol. Med. 10, 555-559.

Hulme AC. 1970. The Biochemistry of fruits and their products. academic press London and New York. 1, 376-377.

Iftikhar S, Imtiaz L, Imtiaz H, Alam Z, Yasser D. 2009. Sensory evaluation and microbial analysis of apple and pear mixed fruit jam prepared from Varieties Grown in Azad Jammu and Kashmir. W. J. D. F. S. 4, 201-204.

Kelly GS. 1999. Squalene and its potential clinical uses. Altern. Med. Rev. 4, 29-36.

Kohno Y, Egawa Y, Itoh S, Nagaoka S, Takahashi M, Mukai K. 1995. Kinetic study of quenching reaction of singlet oxygen and scavenging reaction of free radical by squalene in $n$-butanol. Biochim. Biophys. Acta 1256, 52-56.

Lanzón A, Albi T, Cert A, Gracian J. 1994. The hydrocarbon fraction of virgin olive oil and changes resulting from refining. J. Am. Oil Chem. Soc. 71, 285-291.

Letawe C, Boone M, Pierard GE. 1998. Digital image analysis of the effect of topically applied linoleic acid on acne microcomedones. Clin. Exp. Dermatol. 2, 56-58.

Liu RH, Liu J, Chen B. 2005. Apples prevent mammary tumors in rats. J. Agric. Food Chem. 53, 2341-2343.

Lu Y, Yeap Foo L. 1998. Constitution of some chemical components of apple seed. Food Chem. 61, 29-33.

Marjan S, Melita K, Janez H, Rajko V. 2007. Influence of cultivar and storage time on the content of higher fatty acids. Veg. Crops Res. Bull. 66, 197-203.

Mildner-Szkudlarz S, Jelen HH, Zawirska-Wojtasiak R, Wasowicz E. 2003. Application of headspace-solid phase microextraction and multivariate analysis for plant oils differentiation. Food Chem. 83. 515-522.

Minitab Scan Release 1, 1995. Software for chemomatric analysis. Minitab, state college, PA.

Minnocci A, lacopini P, Martinelli F, Sebastiani L. 2010. Micromorphological, biochemical, and genetic characterization of two ancient, late-bearing apple varieties. J. Hortic. Sci. 75, 1-7.

Oleszek W, Lee CY, Antoni W, Jaworski, Keith RP. 1988. Identification of some phenolic compounds in apples. $J$. Agric. Food Chem. 36, 430-432.

Pearson DA, Tan CH, German JB, Davis PA, Gershwin ME. 1999. Apple juice inhibits human low density lipoprotein oxidation. Life Sci. 64, 1913-1920.

Ramadan MF, Morsel JT. 2003. Oil goldenberry (Physalis peruviana L). J. Agric. Food Chem. 51, 969-974.

Ranalli A, Pollastri L, Contento S, Di Loreto G, lannucci E, Lucera L, Russi F.2002. Sterol and alcohol components of seed, pulp and whole olive fruit oils. Their use to characterise olive fruit variety by multivariates. J. Sci. Food Agric. 82, 854-859.

Robert, C., Paibir, S., Bharaj, S.S., Kelm, G.R., Kulick, R.M., Balm, T.K., Murray, J.V. 2003. The safety of the use of ethyl oleate in food is supported by metabolism data in rats and clinical safety data in humans. Regul. Toxicol. Pharmacol. 37, 133-148.

Rohrer JR, Robertson KR, Phipps JB. 1994. Floral Morphology of Maloideae (Rosaceae) and its systematic Relevance. Am. J. Bot. 81, 574-581.

Standard Methods for the Analysis of Oils, IUPAC 1979. Fats and derivatives edited by C. Paquot, Pergamon Press, Oxford, United Kingdom Statgraphics Plus software package: User's Guide, Release 4.1. 1998. Manugistics, Rockville, Maryland, USA. 9-53.

Tareen MJ, Tareen AQ, Kamal JA, Siddiqui BD. 2003. Influence of. MM-106 and M-9 root stocks on Starking delicious apple. Int. J. Agric. Biol. 5, 339-340.

Traber MG, Atkinson J. 2007. Vitamin E, antioxidant and nothing more. Free Radic. Biol. Med. 43, 4-15.

Velasco J, Dobarganes C. 2002. Oxidative stability of virgin olive oil. Eur. J. Lipid Sci. Technol. 104, 661-676.

Vivacons M, Moreno JJ. 2005. Beta-sitosterol modulates antioxidant enzyme response in RAW 264.7 macrophages. Free Radical Biol. Med. 39, 91-97.

Wasuke K, Chie H, Kiyoko S, Koichiro I. 1987. Studies of ${ }^{13} \mathrm{C}$ NMR spectra of ${ }^{13} \mathrm{C}$-enriched cycloartenol biosynthesized from $\left[1-{ }^{13} \mathrm{C}\right],\left[2-{ }^{13} \mathrm{C}\right]$-and $\left[1,2-{ }^{13} \mathrm{C}_{2}\right]$-acetate. Revised ${ }^{13} \mathrm{C}$ NMR spectral assignments of cycloartenol and ${ }^{13} \mathrm{C}$ NMR spectral support for the generally accepted skeleton formation mechanism of cycloartenol. Magn. Reson. Chem. 25, 683-687.

Wolfe K, Wu XZ, Liu RH. 2003. Antioxidant activity of apple peels. J. Agric. Food Chem. 51, 609-614.

Xiangjiu H, Rui HL. 2008. Phytochemicals of apple peels: Isolation, structure elucidation, and their antiproliferative and antioxidant Activities. J. Agric. Food Chem. 21, 9905-9910.

Yong $\mathrm{H}$, Xiaoli L, Yongni S. 2007. Fast discrimination of apple varieties using Vis/NIR spectroscopy. Int. J. Food Prop. 10, 9-18.

Yu X, van de Voort FR, Li Z, Yue T. 2007. Proximate composition of the apple seed and characterization of its oil. Int. J. Food Eng. 3, 1-8.

Yukui R, Wenya W, Rashid F, Qing L. 2009. Fatty acid composition of apple and pear seed oils. Int. J. Food Prop. 12, 774-779.

Recibido: 4/8/11 Aceptado: 18/11/11 